\title{
Yield, Dry Matter and Specific Gravity of Exportable Potato: Response to Salt
}

\author{
Tuhin Suvra Roy ${ }^{1}$, Rajesh Chakraborty ${ }^{1, *}$, Md. Nahid Parvez ${ }^{2}$, \\ Maruf Mostofa $^{3}$, Jannatul Ferdous ${ }^{3}$, Salma Ahmed ${ }^{4}$ \\ ${ }^{1}$ Department of Agronomy, Sher-e-Bangla Agricultural University, Bangladesh \\ ${ }^{2}$ Department of Agriculture, Faculty of Agriculture, First Capital University of Bangladesh, Bangladesh \\ ${ }^{3}$ Institute of Seed Technology, Sher-e-Bangla Agricultural University, Bangladesh \\ ${ }^{4}$ Institute of Food Science \& Technology, Bangladesh Council of Scientific and Industrial Research (BCSIR), Bangladesh
}

Copyright $\bigcirc 2017$ by authors, all rights reserved. Authors agree that this article remains permanently open access under the terms of the Creative Commons Attribution License 4.0 International License

\begin{abstract}
Maintaining exportable standard of potato is the main bottleneck for the Bangladeshi potato growers and exporters. Bangladesh producing large amount of potato which may give much contribution in world market in future especially in European countries. But, yield and quality of potato is varying with some factors i.e., abiotic, biotic, varietal and nutritional, respectively. From these perspectives, the study was carried out under pot experiment at two consecutive years with due, that; applied chloride may influence the performance of tuber in major salt affected areas where the people wants to grow potato in their field. The experiment consisted of four salt application doses $\left(\mathrm{N}_{0}=\right.$ non-saline, $\mathrm{N}_{1}=5, \mathrm{~N}_{2}=15$ and $\mathrm{N}_{3}=25 \mathrm{~g} \mathrm{NaCl}$ pot $\left.^{-1}\right)$ and three varieties $\left(V_{1}=\right.$ Granula, $V_{2}=$ Lady Rosetta and $\mathrm{V}_{3}=$ Asterix). The pot was arranged following completely randomized design (CRD) with 3 replications. Result revealed that; yield, dry matter and specific gravity were decreased with the increasing of salinity levels. Results demonstrated that, non-saline condition of pot soil is favorable for getting the maximum return from studied parameters. Granula and Lady Rosetta performed the significant similar results in case of studied parameters. Although, Granula showed highest specific gravity at $5 \mathrm{~g}$ $\mathrm{NaCl}$ plot $^{-1}$ which was statistically similar to non-saline condition but, Granula exhibited the highest yield and dry matter under non-saline condition of pot soil. Similar trend was also found in case of Lady Rosetta whereas Asterix performed worst one under highest condition of soil salinity. In, conclusion, it may be said that; potato has sensitivity on salinity for its performances, so, the salt tolerance/salt avoidance varieties should be introduced/developed in our country and the further research should be carried out with how much amount of EC of salinity can be tolerated by exportable potato varieties.
\end{abstract}

Keywords Dry Matter, Exportable Potato, Specific Gravity, Salt, Yield

\section{Introduction}

Potato (Solanum tuberosum L.) is most promising crop among the nightshade family where Bangladesh ranked the $8^{\text {th }}$ position [1] in the world in respect of production. The national average yield and total production in Bangladesh are $19.03 \mathrm{tha}^{-1}$ and 9435150.00 metric tons, respectively [1]. Total production is increasing day by day as such consumption also rapidly increasing in Bangladesh [2]. But, the yield of potato is very low in Bangladesh compared to other potato growing countries like New Zealand (47.74 t $\left.\mathrm{ha}^{-1}\right)$, Netherlands $\left(45.66 \mathrm{t} \mathrm{ha}^{-1}\right)$, USA (47.15 $\left.\mathrm{t} \mathrm{ha}^{-1}\right)$, Japan $\left(30.65 \mathrm{t} \mathrm{ha}^{-1}\right)$, and even in India $\left(22.92 \mathrm{t} \mathrm{ha}^{-1}\right)$. At the same time, Bangladesh has made the position on exportation of quality potato but varietal betterment with exportable standard has not been yet demonstrated as very well. Biotic and abiotic stress may influence the performances of potato in Bangladesh, among these the salinity effects has ability to mention due to the accumulation of chloride in tuber (both in flesh and skin). As a result, the tuber may show the lower yield, dry matter accumulation and specific gravity. In a saline environment, plants take up an excessive amount of sodium at the expense of $\mathrm{K}$ and $\mathrm{Ca}$. Increasing salinity decreased vegetative growth characters [3]. Chloride decreases the specific gravity of tuber instead of sulphate fertilizer [4]. The effects of $\mathrm{NaCl}$ in high air humidity were compared with those of $\mathrm{KCl}$, which is taken up more rapidly [5]. The effects of salt stress on the quality content of potato have not been fully elucidated. To fulfill the above queries of potato tuber the present investigation was aimed to provide the additional dimension on the most responsive salt application and most suitable varieties for better tuber yield, dry matter content and specific gravity in tuber of most promising exportable potato varieties in Bangladesh. 


\section{Methodology}

\subsection{Experimental Site}

Present experiment was settled by plastic pot in research field of Sher-e-Bangla Agricultural University, Dhaka, Bangladesh under transparent plastic paper shade to control unexpected rain in Rabi season from 1 November, 2014 to 20 February, 2015 and 1 November, 2015 to 20 February, 2016.

\subsection{Tested Varieties}

Three most promising exportable potato varieties (i.e., $\mathrm{V}_{1}$ $=$ Granula, $\mathrm{V}_{2}=$ Lady Rosetta and $\mathrm{V}_{3}=$ Asterix) were used as test crop under study.

\subsection{Pot Preparation}

Ionic non-permeable, non-absorbable and water non-leachable but most arable plastic pot was used. The size of the pot was 9.5 inch in diameter and 10.5 inch in height. Each pot was filled with fresh field sandy loam soil $(10.0 \mathrm{~kg}$ dry weight basis).

\subsection{Treatment Application}

The experimental treatments consisted of four salt levels (i.e., $\mathrm{N}_{0}=$ control, $\mathrm{N}_{1}=5, \mathrm{~N}_{2}=15$ and $\mathrm{N}_{3}=25 \mathrm{~g} \mathrm{NaCl} \mathrm{pot}^{-1}$ ). $\mathrm{NaCl}$ was mixed well with the soil before seed tuber planting.

\subsection{Design of the Experimentation}

The plastic pots were arranged following randomized completely randomized design (CRD) with three replications. The total number of plastic pot was 36 .

\subsection{Fertilizer Application}

Each pot was fertilized with $4.0 \mathrm{~g}$ of urea, $5.0 \mathrm{~g}$ of triple super phosphate, $1.5 \mathrm{~g}$ of potassium sulphate, $0.5 \mathrm{~g}$ of gypsum and $0.2 \mathrm{~g}$ of boric acid before seed tuber planting.

\subsection{Planting of Tuber}

Fresh and well sprouted $(50 \mathrm{~g})$ tuber was planted at a depth of $6 \mathrm{~cm}$ in the middle of plastic pot.

\subsection{Watering and Insect-pest Control}

A sufficient amount of water was regularly added to each pot to maintain the soil moisture level at field capacity $(1 / 3$ atm.) of soil water tension through using soil water tensiometer and proper care was taken to prevent leaching of water. Furadon $5 \mathrm{G}$ was applied as per recommendation in pot to control the attack of cricket before planting of tuber. All the plants were keenly observed regularly and Ridomil
Gold and Admire 200 SL were applied as per when weather was much fluctuated to cloudy and rainy to prevent the plant from late blight and aphid and jassid.

\subsection{Parameters Recorded}

The potato haulm (stem) of all pot was pulled out at before 7 days of final harvesting from the pot. All the tuber was harvested at 85 DAP. The most responsive parameter of exportable potato is yield, dry matter content of tuber and specific gravity as standard of export was recorded to analyze.

\subsection{Salinity Reading, EC (dS $\left.\mathrm{M}^{-1}\right)$}

Before the application of salt, the EC reading was collected by using an EC meter from plastic plots and after the harvesting of potato tuber the EC reading was also collected from pot soil.

\begin{tabular}{|c|c|c|c|c|}
\hline Solinity & $\begin{array}{c}\mathbf{N}_{\mathbf{0}} \\
\text { treated } \\
\text { pot }\end{array}$ & $\begin{array}{c}\mathbf{N}_{\mathbf{1}} \\
\text { treated } \\
\text { pot }\end{array}$ & $\begin{array}{c}\mathbf{N}_{\mathbf{2}} \\
\text { treated } \\
\text { pot }\end{array}$ & $\begin{array}{c}\mathbf{N}_{\mathbf{3}} \\
\text { treated } \\
\text { pot }\end{array}$ \\
\hline $\begin{array}{c}\text { Pre-harvest } \\
\text { soil }\end{array}$ & 3.68 & 3.68 & 3.68 & 3.68 \\
\hline $\begin{array}{c}\text { Post-harvest } \\
\text { soil }\end{array}$ & 3.62 & 4.76 & 5.09 & 5.19 \\
\hline
\end{tabular}

\subsection{Statistical Program Used}

For easy interpretation the data from two consecutive year's experimentation with same treatment of salt and same variety were calculated as mean and then used to analyze. All the parameters were analyzed by using ANOVA techniques through Statistix 10 (2013) computer package and means were separated through Least Significant Difference (LSD) techniques at $5 \%$ level of provability.

\section{Results}

\subsection{Salt Application}

\subsubsection{Tuber Yield (g plant $\left.{ }^{-1}\right)$}

Tuber yield due to different doses of salt application was found statistically significant $(\mathrm{p} \leq 0.01)$. A gradual decreasing trend was found with the increasing of salt amount in soil. The highest (415.10g plant ${ }^{-1}$ ) tuber yield was found from $\mathrm{N}_{0}$ and the lowest (347.97g plant ${ }^{-1}$ ) from $\mathrm{N}_{3}$ (Table 1).

\subsubsection{Dry Matter (\%)}

Profound variation $(\mathrm{p} \leq 0.01)$ was found among different doses of salt application on tuber dry matter content (\%). A gradual decreasing trend was found with the increasing of salt amount in soil. The tuber retains maximum (20.91\%) dry matter at $\mathrm{N}_{0}$ whereas minimum $(14.37 \%)$ dry matter of tuber exhibited from $\mathrm{N}_{3}$ (Table 1). 


\subsubsection{Specific Gravity}

Specific gravity of tuber was significantly $(p \leq 0.01)$ influenced by different doses of salt application. A gradual decreasing trend was found with the increasing of salt amount in soil. The tuber produced from $\mathrm{N}_{0}$ treatment exhibited the higher (1.087) specific gravity in volumetric flask with water whereas the lower (0.976) specific gravity was found from $\mathrm{N}_{3}$ (Table 1).

Table 1. Response of salt application on yield, dry matter and specific gravity of potato tuber

\begin{tabular}{|c|c|c|c|}
\hline Salt Application & Tuber Yield $\left(\mathbf{g}_{\text { plant }}{ }^{-1}\right.$ ) & Dry matter (\%) & Specific gravity \\
\hline $\mathrm{N}_{0}$ & $415.10 \mathrm{a}$ & $20.91 \mathrm{a}$ & $1.087 \mathrm{a}$ \\
\hline $\mathrm{N}_{1}$ & $385.41 \mathrm{~b}$ & $18.14 \mathrm{~b}$ & $1.050 \mathrm{~b}$ \\
\hline $\mathrm{N}_{2}$ & $380.87 \mathrm{~b}$ & $16.51 \mathrm{c}$ & $1.033 \mathrm{~b}$ \\
\hline $\mathrm{N}_{3}$ & $347.97 \mathrm{c}$ & $14.37 \mathrm{~d}$ & $0.976 \mathrm{c}$ \\
\hline CV (\%) & $\mathbf{3 . 6 7}$ & $\mathbf{2 . 4 7}$ & $\mathbf{3 . 4 8}$ \\
\hline LSD (0.05) & $\mathbf{1 3 . 7 0}$ & $\mathbf{0 . 4 2}$ & $\mathbf{0 . 0 3}$ \\
\hline F test & $* *$ & $* *$ & $* *$ \\
\hline
\end{tabular}

Numbers in columns followed by the same letter are not statistically different at $\mathrm{P}_{0.05}$.

**, indicates $\mathrm{F}$ test significant at $1 \%$ level of probability.

$\mathrm{N}_{0}=$ non-saline, $\mathrm{N}_{1}=5, \mathrm{~N}_{2}=15$ and $\mathrm{N}_{3}=25 \mathrm{~g} \mathrm{NaCl}$ pot ${ }^{-1}$, respectively.

Table 2. Varietal response to yield, dry matter and specific gravity of tuber

\begin{tabular}{|c|c|c|c|}
\hline Variety & Tuber Yield $\left(\right.$ g plant $\left.^{-1}\right)$ & Dry matter (\%) & Specific gravity \\
\hline $\mathrm{V}_{1}$ & $393.87 \mathrm{a}$ & $18.16 \mathrm{a}$ & $1.057 \mathrm{a}$ \\
\hline $\mathrm{V}_{2}$ & $383.25 \mathrm{a}$ & $17.98 \mathrm{a}$ & $1.045 \mathrm{a}$ \\
\hline $\mathrm{V}_{3}$ & $369.89 \mathrm{~b}$ & $16.31 \mathrm{~b}$ & $1.008 \mathrm{~b}$ \\
\hline CV (\%) & $\mathbf{3 . 6 7}$ & $\mathbf{2 . 4 7}$ & $\mathbf{3 . 4 8}$ \\
\hline LSD (0.05) & $\mathbf{1 1 . 8 6}$ & $\mathbf{0 . 3 6}$ & $\mathbf{0 . 0 3}$ \\
\hline F test & $* *$ & $* *$ & $* *$ \\
\hline
\end{tabular}

Numbers in columns followed by the same letter are not statistically different at $\mathrm{P}_{0.05}$.

**, indicates $\mathrm{F}$ test significant at $1 \%$ level of probability.

$\mathrm{V}_{1}=$ Granula, $\mathrm{V}_{2}=$ Lady Rosetta and $\mathrm{V}_{3}=$ Asterix, respectively.

Table 3. Combined effect of salt application and varieties on yield, dry matter and specific gravity of potato tuber

\begin{tabular}{|c|c|c|c|}
\hline Salt application $\times$ Variety & Tuber Yield $\left(\mathbf{g}\right.$ plant $\left.^{-1}\right)$ & Dry matter (\%) & Specific gravity \\
\hline $\mathrm{N}_{0} \mathrm{~V}_{1}$ & $428.04 \mathrm{a}$ & $22.04 \mathrm{a}$ & $1.109 \mathrm{a}$ \\
\hline $\mathrm{N}_{0} \mathrm{~V}_{2}$ & $416.11 \mathrm{ab}$ & $21.58 \mathrm{a}$ & $1.087 \mathrm{ab}$ \\
\hline $\mathrm{N}_{0} \mathrm{~V}_{3}$ & $401.15 \mathrm{bc}$ & $19.11 \mathrm{ab}$ & $1.057 \mathrm{abc}$ \\
\hline $\mathrm{N}_{1} \mathrm{~V}_{1}$ & $388.06 \mathrm{~cd}$ & $18.67 \mathrm{bc}$ & $1.047 \mathrm{bc}$ \\
\hline $\mathrm{N}_{1} \mathrm{~V}_{2}$ & $386.11 \mathrm{~cd}$ & $18.04 \mathrm{~cd}$ & $1.045 \mathrm{bc}$ \\
\hline $\mathrm{N}_{1} \mathrm{~V}_{3}$ & $382.08 \mathrm{~cd}$ & $17.71 \mathrm{de}$ & $1.037 \mathrm{bc}$ \\
\hline $\mathrm{N}_{2} \mathrm{~V}_{1}$ & $380.24 \mathrm{~cd}$ & $16.40 \mathrm{fg}$ & $1.036 \mathrm{bc}$ \\
\hline $\mathrm{N}_{2} \mathrm{~V}_{2}$ & $385.25 \mathrm{~cd}$ & $17.05 \mathrm{ef}$ & $1.027 \mathrm{bc}$ \\
\hline $\mathrm{N}_{2} \mathrm{~V}_{3}$ & $377.12 \mathrm{~d}$ & $16.08 \mathrm{gh}$ & $1.027 \mathrm{bc}$ \\
\hline $\mathrm{N}_{3} \mathrm{~V}_{1}$ & $379.15 \mathrm{~cd}$ & $15.52 \mathrm{hi}$ & $1.011 \mathrm{c}$ \\
\hline $\mathrm{N}_{3} \mathrm{~V}_{2}$ & $345.55 \mathrm{e}$ & $15.23 \mathrm{i}$ & $0.891 \mathrm{~d}$ \\
\hline $\mathrm{N}_{3} \mathrm{~V}_{3}$ & $319.21 \mathrm{f}$ & $12.34 \mathrm{j}$ & $\mathbf{3 . 4 8}$ \\
\hline $\mathbf{C V}(\mathbf{\%})$ & $\mathbf{3 . 6 7}$ & $\mathbf{2 . 4 7}$ & $\mathbf{0 . 0 6}$ \\
\hline LSD $(\mathbf{0 . 0 5})$ & $\mathbf{2 3 . 7 2}$ & $* .73$ & $*$ \\
\hline F test & $*$ & $* *$ & \\
\hline
\end{tabular}

Numbers in columns followed by the same letter are not statistically different at $\mathrm{P}_{0.05}$.

**, indicates $\mathrm{F}$ test significant at $1 \%$ level of probability and *, indicates $\mathrm{F}$ test significant at $5 \%$ level of probability.

$\mathrm{N}_{0}=$ non-saline, $\mathrm{N}_{1}=5, \mathrm{~N}_{2}=15$ and $\mathrm{N}_{3}=25 \mathrm{~g} \mathrm{NaCl}$ pot $^{-1}$, respectively.

$\mathrm{V}_{1}=$ Granula, $\mathrm{V}_{2}=$ Lady Rosetta and $\mathrm{V}_{3}=$ Asterix, respectively. 


\subsection{Varietal Response}

\subsubsection{Tuber Yield $\left(\mathrm{g} \mathrm{plant}^{-1}\right)$}

There was profound variation $(\mathrm{p} \leq 0.01)$ among three varieties on potato tuber yield. A gradual decreasing trend was found from Granula to Asterix. The highest (393.87g plant $^{-1}$ ) tuber yield was found from $V_{1}$ which was statistically similar to $V_{2}\left(383.25 \mathrm{~g} \mathrm{plant}^{-1}\right)$ and the lowest $(369.89 \mathrm{~g}$ plant ${ }^{-1}$ ) from $V_{3}$ (Table 2).

\subsubsection{Dry Matter (\%)}

Remarkable variation $(\mathrm{p} \leq 0.01)$ was found among three varieties on tuber dry matter content (\%). A gradual decreasing trend was found from Granula to Asterix. The maximum (18.16\%) dry matter of tuber was found from $\mathrm{V}_{1}$ which was statistically similar to $V_{2}(17.98 \%)$ and the minimum (16.31\%) from $\mathrm{V}_{3}$ (Table 2).

\subsubsection{Specific Gravity}

Tuber specific gravity due to three varieties was found significant $(p \leq 0.01)$. A gradual decreasing trend was found from Granula to Asterix. The tuber produced from $\mathrm{V}_{1}$ variety exhibited the higher (1.057) specific gravity in volumetric flask with water which was statistically similar to $V_{2}(1.045)$ whereas the lower (1.008) specific gravity was found from $\mathrm{V}_{3}$ (Table 2).

\subsection{Combined Effect}

\subsubsection{Tuber Yield $\left(\right.$ g plant $\left.^{-1}\right)$}

Profound variation $(p \leq 0.05)$ was found from the combination of different salt application and three varieties on tuber yield of potato. The $\mathrm{N}_{0} \mathrm{~V}_{1}$ combination showed the highest (428.04g plant ${ }^{-1}$ ) tuber yield which was statistically similar to $\mathrm{N}_{0} \mathrm{~V}_{2}\left(416.11 \mathrm{~g}\right.$ plant $\left.^{-1}\right)$ and the lowest $(319.21 \mathrm{~g}$ plant ${ }^{-1}$ ) yield was found from $\mathrm{N}_{3} \mathrm{~V}_{3}$ (Table 3).

\subsubsection{Dry Matter (\%)}

Dry matter content of potato due to combination of different salt application and three varieties was found statistically significant $(\mathrm{p} \leq 0.01)$. The $\mathrm{N}_{0} \mathrm{~V}_{1}$ combination showed the maximum $(22.04 \%)$ dry matter partitioning in tuber which was statistically similar to $\mathrm{N}_{0} \mathrm{~V}_{2}(21.58 \%)$ and $\mathrm{N}_{0} \mathrm{~V}_{3}(19.11 \%)$ and the minimum (12.34\%) dry matter was partitioned in the plant produced from $\mathrm{N}_{3} \mathrm{~V}_{3}$ (Table 3).

\subsubsection{Specific Gravity}

Remarkable variation $(p \leq 0.01)$ was found from the combination of different salt application and three varieties on specific gravity of potato tuber. The $\mathrm{N}_{0} \mathrm{~V}_{1}$ combination exhibited the higher (1.109) specific gravity in tuber which was statistically similar to $\mathrm{N}_{0} \mathrm{~V}_{2}(1.087), \mathrm{N}_{0} \mathrm{~V}_{3}(1.067)$ and $\mathrm{N}_{1} \mathrm{~V}_{1}(1.057 \%)$ and the lower $(0.891 \%)$ specific gravity was found from the plant produced from $\mathrm{N}_{3} \mathrm{~V}_{3}$ (Table 3).

\section{Discussion}

\subsection{Tuber Yield (g plant $\left.{ }^{-1}\right)$}

Normally, potato shows its sensitivity towards salinity in leaves, stems and tuber. The highest tuber yield is resulted from higher tuber weight per unit area and higher number of tuber per unit area. A significant decline in potato yield is along with the increasing salinity $[6,7]$. The accumulation of chlorides may reduce the average tuber weight resulted the reduced tuber yield per unit. The yield reduction under saline conditions might be related to delayed emergence hindering tuberization and tuber enlargement, which ultimately decreases the number of tubers per plant and average tuber yield per plant in plastic pot. The lower tuber yield may be attributed for lower protein content of tuber at high levels of salinity [8]. [9] also reported that the non-saline condition was superior for all growth traits of potatoes. [10, 11] reported that, the total tuber weight and average tuber weight was low under high saline condition of soil than non-saline condition and [12] also found that increasing salinity of irrigation water significantly reduced average and total tuber yield for all cultivars of potato. So, Granula and Lady Rosetta exhibited the highest tuber yield at non-saline condition.

\subsection{Dry Matter (\%)}

Dry matter accumulation needs more and more partitioning of total soluble solid $\left(\mathrm{TSS}^{\circ}\right)$ in the tuber and the amount of TSS may maintain the amount of dry matter content in tuber. The salinity may reduce the dry matter content through accumulation of higher chloride in tuber. High salt in soil or irrigation water or fertilizers will also lower the dry matter (specific gravity) of potatoes [13]. Salinity also reduces the dry matter in sugar Beet [14]. The partitioning of assimilates to tubers might be affected by salinity as tuber growth is reduced to a greater extent than canopy growth [15]. The higher reduction of dry matter production resulted in a greater reduction of tuber yield as tuber growth was more susceptible under salt-stressed conditions. So, Granula and Lady Rosetta produced the maximum dry matter at non-saline condition.

\subsection{Specific Gravity}

Lower dry matter content of tuber and lower weight of tuber result the lower specific gravity. With the increasing of chlorine accumulation in tuber the specific gravity trend is decreasing. Specific gravity is generally employed as a measure of tuber quality since it is highly correlated with the starch content $[16,17]$. Salinity decreases the tuber specific gravity to a smaller extent and slightly degrades the tuber quality. Higher salt accumulation may raise the levels of nitrogen $(\mathrm{N})$, presumably due to the decrease in the carbohydrate content in the tubers. As a result, the specific gravity was reduced per tuber. The decrease in the specific gravity may also be related to the higher chloride content 
(anions predominating) of the salt-treated plants [18].

[19] also reported that, fertilizer materials with higher salt indices will decrease specific gravity more than fertilizer materials with lower salt indices. So, Granula and Lady Rosetta produced the higher specific gravity at non-saline condition.

\section{Conclusions}

Soil is the powerhouse nutrients for crops but, the inborn/residual crop nutrients or inborn ions may verify the performances of its flora. Potato is the most sensitive to chloride ions among solanaceae family. Granula is now exporting from Bangladesh as it contains the exportable standard. The Lady Rosetta and Asterix are now considering exporting from Bangladesh due to these screened from many trials by pronounced researchers with exportable standard as Granula. So, from the present investigation, it may be said that, salt application influenced the yield, dry matter and specific gravity of three most promising exportable potato varieties of Bangladesh. These three traits showed the maximum return from $\mathrm{N}_{0} \mathrm{~V}_{1}$ (control/non-saline and Granula) combination and in spite of chloride accumulation in potato tuber cell, Granula may also be cultivated at saline condition as it exhibited the statistically higher specific gravity at $5 \mathrm{~g}$ $\mathrm{NaCl}$ pot $^{-1}$ as non-saline condition.

\section{Limitation and Further Suggestion}

\subsection{Limitation}

All the interpretation and recommendation needs to more and more trials under experimentation. But, in our present study we take only the mean data of two consecutive years with same salt treatment and same variety in plastic pot. It should had been to take data on field basis with same experiment. Economic returns had not been calculated under present study.

\subsection{Further Suggestion}

Since, the salinity influenced the growth, yield and quality of potato plant and tuber. The further researcher should be taken data on electrical conductivity EC $\left(\mathrm{dS} \mathrm{m} \mathrm{m}^{-1}\right)$ against different salt doses under field condition. The data on different major salt affected areas where potato production may be or may not be recommended in Bangladesh should be taken. Salt tolerant potato variety should be adopted through varietal screening.

\section{Author Contribution}

Prof. Roy and Mr. Chakraborty thought the present study and Professor Roy arranged all the facilities to conduct and finally he reviewed the manuscript till the present form. Mr. Chakraborty collected the data on different parameters and arranged for statistical analysis. $\mathrm{He}$ also wrote the manuscript. Rest of all authors helped to data collection and review collection.

\section{Acknowledgement}

All authors would like to expresses their special word of thanks to financial body due to the research was carried out by the partial framework of JSPS (Japan Society for the Promotion of Science), Japan-UGC (University Grant Commission), Bangladesh, collaborative project.

\section{Conflict of Interest}

The authors declares no potential conflict of interest under present study and the authors says that, no part of this manuscripts have been published elsewhere in any form.

\section{REFERENCES}

[1] FAOSTAT (2014). Statistical Database. Food and Agricultural Organization of United Nations, Rome, Italy (http://www.fao.org/faostat/en/\#data/QC, retrieved on-25 December, 2016).

[2] Roy T. S., Baque M. A., Chakraborty R., Haque M. N., Suter P. (2015). Yield and Economic Return of Seedling Tuber Derived from True Potato Seed as Influenced by Tuber Size and Plant Spacing. Univ J Agril Res 3(1): 23-30.

[3] Evers D., Overney S., Simon P., Greppin H., Hausman J. F. (1999). Salt tolerance of Solanum tuberosum L. overexpressing a heterologous osmotin-like protein. Biol Plant 42(1): 105-112.

[4] Murphy, H. J., Goven, M. J. (1959). Factors affecting the specific gravity of the white potato in Maine. Maine Agril Expt Stn Bull 583.

[5] Backhausen J. E., Klein M., Klocke M., Jung S., Scheibe R. (2005). Salt tolerance of potato (Solanum tuberosum L. var. Desiree) plants depends on light intensity and air humidity. Plant sci 169(1): 229-237.

[6] http://www.demofarm.ca/pdf-2006/IB004-2005.pdf (Retrieved on 24 December, 2016).

[7] Karam F., Katerji N., Mastrorilli M., Van Hoorn J. W., Hamdy A. (1993). Effects of irrigation water salinity and soil texture on potatoes growth and production. In: Intl Symp. on Water Quality and Quantity-Greenhouse 458: 89-94.

[8] Ahmad R. A. F. I. Q., Abdullah Z. (1979). Salinity induced changes in the growth and chemical composition of potato. Pakistan J Bot 1: 103-112.

[9] Rahman M. H., Islam R., Hossain M., Haider S. A. (2008). Differential Response of Potato under Sodium Chloride Stress Conditions In-vitro. J Bio-Sci 16: 79-83. 
[10] Patell R. M., Prasher S. O., Donnelly D., Bonnell R. B. (2001). Effect of initial soil salinity and subirrigation water salinity on potato tuber yield and size. Agril Water Manag 46(3): 231-239.

[11] Samy M. M. (2015). Effect of Irrigation with Saline Water on the Growth and Production of Some Potato Cultivars. Sci 5(4): 1151-1163.

[12] El-Khatib H. A., Elkhatib E. A., Khalaf Allah A. M., El-Sharkawy A. M. (2004). Yield response of salt-stressed potato to potassium fertilization: A preliminary mathematical model. J plant nutr 27(1): 111-122.

[13] https://www.agric.wa.gov.au/water-management/mid-west-p otatoes-irrigation-salinity-and-harvest-management?nopagin $\mathrm{g}=1$ ((Retrieved on 25 December, 2016).

[14] Dadkhah A. R., Grrifiths H. (2010). The effect of salinity on growth, inorganic ions and dry matter partitioning in sugar beet cultivars. J Agril Sci Technol 8: 199-210.

[15] Levy D. (1992). The response of potatoes (Solanum tuberosum L.) to salinity: plant growth and tuber yields in the arid desert of Israel. Ann Appl Biol 120: 547-555.

[16] Prince F. S., Blood P. T., Coates W. H. (1940). Experiment with potatoes. Bull New Hamps Agric Expt Stn 324.

[17] Kelly W. C. Smith O. (1944). Specific gravity determination as an aid in research. American Soc Hort Sci Proc 44: 329-333.

[18] Smith O., Nash L. B. (1941). Potato quality. III. Relation of soil reaction, irrigation and mineral nutrition to cooking quality. In: Proc. American Soc Hort Sci 38: 507-512.

[19] Laboski C. A. Kelling K. A. (2007). Influence of fertilizer management and soil fertility on tuber specific gravity: a review. American J Potato Res 84(4): 283-290. 